\title{
Industry 4.0 in development of new technologies for underground mining
}

\author{
Dorota Pataka $^{*}$, Bartosz Paczesny ${ }^{2}$, Marcel Gurdziel ${ }^{2}$, and Wiktoria Wieloch ${ }^{2}$ \\ ${ }^{1}$ Silesian University of Technology, Faculty of Organization and Management, Roosevelta 26, \\ 41-800 Zabrze, Poland \\ ${ }^{2}$ Wrocław University of Technology, Faculty of Geoengineering, Mining and Geology, ul. Na Grobli \\ 15,50-421 Wrocław
}

\begin{abstract}
Students of the Faculty of Geoengineering, Mining and Geology of the Wrocław University of Technology, together with engineers from KWK ROW Ruch Chwałowice, a part of Polska Grupa Górnicza S.A., conducted a survey among the group of underground workers. The selected target group included mechanical fitters, electricians and miners. The survey concerned the development of new technologies for underground coal mining. It was developed so that its form is understandable to the respondents. It contained 15 questions and the respondents were asked to choose only one answer for each question. The questionnaire was anonymous and contained questions about the period of seniority and the age of the respondent. The article presents opportunities arising from the introduction of Industry 4.0 in the context of improving safety and increasing coal production in underground mining. A historical view of industrial revolutions was developed based on available publications in order to briefly present the idea of Industry 4.0.
\end{abstract}

\section{Introduction}

People have been driven by a need to develop technology for centuries. Technological progress initiates change in production processes, economy, society and culture. The latest industrial revolution started. But how did the industry function before it? What gave rise to industrial revolutions and when did they occur? An industrial revolution is the transition from the manufacturing industry to the factory industry and then to machine manufacturing. Numerous factories, steelworks and mines were established. The standard of living of people increased, and the level of mechanisation of work allowed to limit the number of people needed to perform arduous and hard works. The development of education increased the need for cultural development of society. Schools, academies and theatres were established. The transport industry expanded.

Development of the mining industry based on Industry 4.0 requires the introduction of innovative solutions to improve working conditions [3] as well as the development of new technologies [2]. Nowadays, the use of the advantages of Industry 4.0 may contribute, among other things, to combating natural hazards $[17,20]$. There are numerous types of such hazards but the main one is methane hazard $[16,18,19]$. Another is endogenous and

* Corresponding author: dorota.palka@polsl.p1 
exogenous fires [12]. Tremors impact the excavation decreasing the strength of machines in the entire complex $[14,15]$. Global hard coal mining must apply solutions based on the concept of Industry 4.0 to ensure continuous growth in electricity demand. The paper presents the results of a survey that allowed to understand the way mine workers see innovative solutions.

\section{Brief historical background of industry 1.0 to 4.0}

\subsection{Industry 1.0}

The eighteenth century is considered to be a turning point. The population of Europe was constantly growing. There were many social, cultural and economic changes. Thanks to numerous new discoveries and inventions, the industry expanded rapidly. Great Britain was then a leading economic power. The first machine to improve the weaving industry was built in 1733 by John Kay. The machine that revolutionised the weaving industry, however, was the spinning machine based on a water wheel used as a mechanical drive. It was constructed by Samuel Crompton in 1779. The use of a water wheel was not possible under all conditions and was not as effective in other fields of industry, for instance in the food industry. There, technologies that did not undergo constant improvement, could not cope with the growing population and crops. This was especially true for mills where a water wheel was used. A steam machine was then invented, which replaced the energy of water flow with energy from steam. It was used to pump out water from the mine, supply water to homes or extinguish fires $[4,7]$.

\subsection{Industry 2.0}

In the second half of the nineteenth century, the United States and Germany were the largest economic powers in the world. The beginning of the second industrial revolution is estimated to start in 1870s. The universities were dominated by the science faculties that supplied the industry with engineers. This has resulted in a rapid development of science. New technological solutions were developed. Electricity and an assembly line spread. Henry Ford was the first one to use the belt organization of work in car assembly. Instead of being assembled at one station, the vehicles were produced in stages at different stations. The car production process became more dynamic and production costs were significantly reduced [4]. In addition, chemical synthesis was used, which helped the development of the chemical industry. The engineering industry was growing thanks to mass production of steel. The telephone and the telegraph were in common use $[4,10]$.

\subsection{Industry 3.0}

The next revolution took place in the 1970s. It is regarded as a scientific and technological revolution. The symbol of the that era were industrial districts-technopoles. The distribution of the population became more dependent on the proximity of universities and access to qualified staff. The fields of science were merging, which significantly accelerated the development of technology. Newer and more advanced technologies were implemented into production processes [11]. Partial automation took place through the use of electronic systems and information technology increasing the performance of machines. Their efficiency, efficacy and precision were boosted. Research on increasing control over the production process by machines started. The most important inventions of this 
revolution are microprocessors and the microcomputers. At the end of the 1990s, computers were connected as a large global network $[4,10]$.

\subsection{Industry 4.0}

The beginning of the second industrial revolution is estimated to start in 2010s. The concept of Industry 4.0 is about blurring the barriers between the real world of production machines and the virtual world of the Internet and information technology. The idea is to create factories that will form a closed circuit of information flow. People, machines, IT systems are to be integrated and automatically exchange information during production. Implementation of solutions of Industry 4.0 significantly reduces production costs and enables the creation of customized products. All these advantages help a company to improve all of its departments and compete with other companies $[4,10]$.

\section{Longwall complex for hard coal mining}

Most of the machines used in the hard coal mining industry were built in the 3.0 era of industry. It was characterized by the automation of industrial production, but it did not exclude the human factor that operates the machines. This increased the efficiency of the mine and gradually improved safety.

Longwall shearers are used in the exploitation of hard coal deposits and cooperate with a powered roof support and a scraper conveyor. The general principle of a longwall shearer is very simple. It mines the body of coal by moving forward on a longwall conveyor.

A powered roof support is he device that has significantly contributed to the improvement of safety in underground excavations. In addition to safety functions, it is also used to move the mining machine and the longwall conveyor as the operation progresses. The powered roof support consists of parts necessary for its operation, transmitting forces and loads, these include: a leg, a canopy, a floor base, a shield support, connectors, pins or side guards. Other elements are the accessories necessary for the operation of the roof support, but they do not carry the loads of the rock mass [13].

Finally, there are machines transporting the output. Scraper conveyors and belt conveyors are used in the Polish mining industry [1]. The general principle of operation of scraper conveyors is based on continuous movement of the output using transverse elements called scrapers. Scraper conveyors can be divided according to various criteria such as type of construction, place of application or number of motors.

Another type of conveyors are belt conveyors. They are mainly intended for collective transport from longwall faces where high amount of coal is extracted. The pulling element, at the same time carrying the excavated material, is a continuous belt. It moves on rollers called pulleys which are placed on supports. The movement is initiated by a drive drum that is rotated by the motor via a gearbox. An important parameter that has a significant impact on the performance of the belt system is the shape of the carrier belt. The parameters of the belts are selected based on the conditions in which the works will be performed [5].

\section{Selecting a machine for industry 4.0 development}

When choosing a machine which would be most useful for the development process, one should not only be guided by the scope of operation of individual machines. The operating range of one device is only one link in the production chain. The entire production process must be taken into account, the aim being to eliminate the points in the process that cause the greatest risks and the greatest downtime to make mining operations more efficient and 
safer. In the process of longwall coal mining, the greatest hazards are generated at the place where the powered roof supports move. This is also the device that most effectively protects workers from rocks falling from the roof. Automation and modernization of the longwall complex can significantly contribute to the efficiency, efficacy and safety of a mine.

One of the most famous slogans behind the idea of Industry 4.0 is machine learning. Its essence lies in the fact that tasks previously reserved only for people will soon be entrusted to machines. Until now, the work done by the machines has been repetitive and routine, because the machines could not cope with new problems, but those times are over. Our mechanical associates can be equipped with a set of sensors used to collect information about their work. Once enough data is collected, the machine's intelligence will allow it to find patterns that will allow it to identify hazards. The introduction of such a system will allow machines to work more efficiently and solve more complex problems.

Large stoppages may be caused by the need to carry out repairs and maintenance work on the equipment. Industry 4.0 provides the opportunity to implement a system which would allow for the prediction of the service life of individual machine components and the timing of their replacement. Diagnosis of faults, detection of unnatural behaviour of the machine and warnings will allow to fix the issues more quickly [6]. Therefore, the operators of the machines will not be forced to constantly monitor the parameters and they will be able to prepare themselves for the mining process. To achieve this, machines would first gather information about the nature of the work they are doing and, once enough data has been collected by means of machine learning, they could see repetitive patterns and, on the basis of these patterns, predict a need to replace an item or detect a high risk of damaging the item.

Full automation may be a solution that will increase the efficiency of the longwall complex. There are many examples around the world that show that the introduction of automation into a longwall complex significantly contributes to the efficiency of the mining process. The lack of automation generates production stoppages between shifts as another operator needs time to reach the location. The need for human operation and supervision causes also considerable numbers of stoppage. The idea of automation is to eliminate the operation of devices from the longwall complex. Persons supervising the work of a shearer and roof support or operating its mining rate are particularly exposed to hazard occurring in the mine. The ideal solution would be to leave only one specialist who could supervise all parameters of the longwall complex and interfere with its operation only when necessary. This solution was applied at the Yalevskogo Russian coal mine located in Kuzbass, Siberia. In May 2017, this mine set a new national record in coal extraction from a single longwall in one month-1,407,300 tonnes. Interestingly, the previous record belonged to the same mine and was set in August 2016 and amounted to 1,050,452 tonnes. Record-breaking performance was achieved while maintaining the highest national safety standards, with no accidents involving workers. The longwall complex was equipped with a powered roof support manufactured by Caterpillar and was located in a seam of average thickness of 4 metres. The complex was fully automated and the conditions in the longwall were monitored in real time. The system also enabled remote diagnostics of all equipment in the longwall complex, and all information was sent to the surface for maximum efficiency [9].

Such solutions will limit number of people working in the longwall, but the highest level of safety measures must be maintained to provide safe working conditions for the remaining workers. The sensors can be mounted in the roof support and monitor the state of the rock mass on an ongoing basis, being in constant communication with each other. Using databases and machine learning, sensor data will enable machines to predict the occurrence of energy discharges from the rock mass, which can prevent accident, including fatal ones. The system is being used worldwide and has managed to demonstrate its usefulness in 
China, where it predicted a cave-in in the Sanhejian coal mine [21]. There are many versions of this system with different sets of parameters read from the rocks including changes in magnetic field intensity, temperature measurement of the opposite sides of the excavation by means of infrared and the use of sensors working in fibre optic technology [22].

\section{Conclusion}

Industrial revolutions have been always defined by the invention of a certain device or a discovery that gave rise to new possibilities. The development of new capabilities has boosted the industry. When further development of a device was no longer possible a new invention was needed. Such pattern of development and breakthrough discoveries has been working for hundreds of years. Industry 4.0 will have a different impact on human work than other industrial revolutions. It will not lead to full automation of all aspects of the industry. It will rather affect the way people, machines and technologies communicate with each other.

Routine tasks such as repairs and maintenance of the machines will be easier and cheaper. A modern longwall system consisting of a longwall shearer, a powered roof support and belt and scraper conveyors is relatively efficient when properly adjusted. If outdated, however, it limits the volume of output that could be extracted with the use of more innovative solutions and simultaneously impact on the level of safety in the mine, preventing the mining potential to be fully exploited. Some countries, not wanting to fall behind the rest of the world in the face of the new industrial revolution, have for several years now consistently introduced programs aimed at making Industry 4.0 part of their economy. These are Germany, where the Industry 4.0 strategy was formed in 2013, China with Made in China 2025 program and Society 5.0 in Japan [9]. If Poland strives to be a part of global economy, it should also start implementing new technologies as soon as possible. There are only few pioneers in Poland working in the field of Industry 4.0 technology when it comes to creating large databases. Polish companies are at the tail end of the list of European countries. Polish industry faces many challenges, but also great opportunities. Much can be gained by preparing well for the upcoming changes.

\section{References}

1. R. Błażej, M. Bajda, M. Hardygóra, Acta Montanistica Slovaca. 22:2, 116-125 (2017)

2. J. Brodny, M. Tutak, Energies, 12:13, 2505 (2019)

3. J. Brodny, M. Tutak, Int. J. Environ. Res. Public Health, 15:9, 1846 (2018) doi.org/10.3390/ijerph15091846

4. Desoutter, Rewolucja przemystowa - od Przemystu 1.0 do Przemystu 4.0. URL: https://www.desouttertools.pl/przemysl-4-0/wiadomosci/606/rewolucja-przemyslowaod-przemyslu-1-0-do-przemyslu-4-0

5. L. Gładysiewicz, R. Król, W. Kisielewski, D. Kaszuba, Acta Montanistica Slovaca, 22:2, 206-214 (2017)

6. A. Gonfalonieri, How to Implement Machine Learning for Predictive Maintenance by towards data science. URL: https://towardsdatascience.com/how-to-implementmachine-learning-for-predictive-maintenance-4633cdbe 4860

7. iTechBlo, Rewolucja przemystowa - przyczyny, skutki, etapy, wynalazki. URL: http://itechblog.pl/rewolucja-przemyslowa-przyczyny-skutki-etapy-wynalazki 
8. J. Lööw, L. Abrahamsson, J. Johansson, Mining, Metallurgy \& Exploration, 36, 701707 (2019)

9. Mining Customer Stories, Russian mine sets monthly coal production record. URL: http://s7d2.scene7.com/is/content/Caterpillar/CM20170920-48150-19043 [Accessed 22 Jan. 2019]

10. M. Partnerski, Cztery rewolucje przemystowe. Od maszyny parowej do powszechnej cyfryzacji. URL : https://superbiz.se.pl/wiadomosci/cztery-rewolucje-przemyslowe-odmaszyny-parowej-do-powszechnej-cyfryzacji-aa-peK9-ZE76-HoaT.html

11. Z. Piątek, Czym jest przemyst 4.0? URL: http://przemysl40.pl/index.php/2017/03/22/czym-jest-przemysl-4-0/

12. D. Szurgacz, L. Sobik, J. Brodny, Multidiscip. Aspe. of Produ. Engine., 2:1,183-190 (2019). DOI: doi.org/10.2478/mape-2019-0018

13. D. Szurgacz, Zmechanizowana obudowa ścianowa $w$ zmiennych warunkach górniczogeologicznych (Oficyna Wydawnicza Politechniki Wrocławskiej, Wrocław, 2019)

14. D. Szurgacz, J. Brodny, SGEM, 1.3, 793-800 (2018). DOI:doi.org/10.5593/sgem2018/1.3

15. D. Szurgacz, J. Brodny, E3S Web Conf., 41, 03019 (2018)

16. M. Tutak, M. Sustainability, 12:1, 16 (2020)

17. M. Tutak, J. Brodny, Appl. Sci., 9:24, 5315 (2019). URL: doi.org/10.3390/app9245315

18. M. Tutak, J. Brodny, Energies, 12:20, 3840 (2019)

19. M. Tutak, J. Brodny, Int. J. Environ. Res. Public Health, 16:8, 1406 (2019). DOI :doi.org/10.3390/ijerph16081406

20. M. Tutak, J. Brodny, Energies, 11:11, 3076 (2018)

21. P. Yuanyuan, D. Apel, V. Liu, H. Mitri, International Journal of Mining Science and Technology, 29:4, 565-570 (2019)

22. S. Zengrong, L. Tongyu, S. Guangdong, H. Binxin, J. Long, S. Zenghua, W. Qi, S. Tong, T V G. Kenneth, IOP Conf. Series: Journal of Physics: Conf. Series, 1065, 252018 (2018) 